\title{
Relooking at the Common Core Standards Through the Lens of Equity - Closing the Achievement Gap
}

\author{
Dr. N. K. Rathee \\ Director, Education Graduate Programs \& Associate Professor \\ Delaware State University, Dover, DE, USA
}

doi: 10.19044/esj.2017.v13n22p1 URL:http://dx.doi.org/10.19044/esj.2017.v13n22p1

\begin{abstract}
On the failure of No Child Left Behind (NCLB) to close the "achievement gap" between whites and minorities, the Common Core State Standards were heralded as the best way of raising academic standards for all children around the country and closing the achievement gap. Numerous reports have emerged questioning the efficacy of the Common Core Standards to deliver what was promised. Public disillusion is apparent. This paper is an attempt to revisit the Common Core Standards through the lens of data generated by its implementation. Quantitative data available from the National Assessment of Educational Progress (NAEP) for $4^{\text {th }}, 8^{\text {th }}$ and $12^{\text {th }}$ grade students and their achievements scores for mathematics and reading for the years 2009, 2011, 2013 and 2015 were taken into consideration. Results have revealed no increase, much less significant, in the average achievement scores and no indication that the achievement gap was being narrowed. Recommendations have been made for having a relook at the content and the implementation of the standards.
\end{abstract}

Keywords: Common Core, Achievement Gap, Academic Achievement

\section{Introduction}

Debate and discussion about what should be taught in schools, from math, science and social studies, to music and art, reading and writing, has been going on for many decades. In 1965, the Elementary and Secondary Education Act (ESEA) came to be enacted with the aim of narrowing achievement gaps by providing every child with a fair and equal opportunity to achieve an exceptional education. In 1983, the National Commission on Excellence in Education in its report A Nation at Risk described a "rising tide" of mediocre schools that threatened the nation's future. In 1983 itself, the nation's first blue-ribbon school study commission endorsed that the public high schools across the nation should provide a rigorous academic 
education for all students who sought it, not just for the elite going on to college. To meet the requirements of the employers and the higher education institutions, the "Standards \& Accountability Movement" began 1990s as the states started developing standards that focused on what the students were expected to know and to be able to do at each grade level, and also to design the assessments to measure whether the standards were being met.

Around 2008, it was felt that in order for America to lead the world in innovation and to remain competitive, it was necessary to have an internationally competitive education system. With this aim in mind, a task force composed of commissioners of education, governors, corporate chief executive officers and recognized experts in higher education was created. This task force submitted it report in December 2008 which laid the foundations of the Common Core Standards. It was on June 2, 2010 when the Standards for mathematics and English language arts became available. The main objective of these standards was to "provide a consistent, clear understanding of what students are expected to learn, so that the teachers and parents know what they need to do to help them." Apart from that, "The standards were designed to be robust and relevant to the real world, reflecting the knowledge and skills that our young people need for success in college and careers," to prepare our students to compete in a global economy.

A majority of states adopted these standards in the subsequent months. These Standards suggested significant changes in the education that not only affected the students, their learning styles and practices but also affected the way the teachers developed their lessons and the method students were to be taught. These Standards also had the new assessments that were aligned to the Standards to measure college and career readiness. (Jones \& King, 2012).

Since their adoption, controversy has surrounded the effectiveness of the Common Core State Standards. Concerns have been raised that the standards were causing harm instead of the benefits, and at least 12 states have introduced legislation prohibiting the implementation of these standards. Three states namely Indiana, Oklahoma, and South Carolina had initially adopted Common Core but since then have decided to repeal or replace these standards.

Ostashevsky (2016) has stressed that even after more than five years after adopting Common Core, Kentucky's black-white achievement gap is widening. She has reported that according to Kentucky Department of Education "in spring 2015, in the elementary grades, 33 percent of black students were proficient in reading, versus 58 percent of white students; in math, the breakdown was 31 percent to 52 percent. And those gaps, in many cases, have widened". On similar lines, Reese (2016) reported that in 2016, 
the achievement gap grew after adopting the California Common Core Standards. The test scores in California improved during the year 2016, as observed by Reese (2016), but the test score gap between the haves and have-nots got wider. The National Assessment of Educational Progress (NAEP) Long-Term Trend Assessments 2012 found that the achievement gaps for 17-year-old black and Hispanic students have not improved since the early 1970s although such gaps declined for 9 and 13-year olds until the mid- to late-1980s. (Robelen, 2013). This paper is an attempt to have a relook at the effectiveness of the Common Core Standards and their impact on reducing the achievement gap among diverse student population.

\section{Methodology}

This paper examined the quantitative data available from the National Assessment of Educational Progress (NAEP). It focusses on the data available for to three categories, (i) students' economic status, (ii) gender, and (iii) the race. The students were studying in $4^{\text {th }}, 8^{\text {th }}$ and $12^{\text {th }}$ grades and their achievements scores for mathematics and reading for the years 2009, 2011, 2013 and 2015 were taken into consideration

\section{Results and Discussion}

For the purpose of the analysis of data, the scores obtained by the students falling in eligible and not eligible categories under the National School Lunch Program were taken into consideration to differentiate the students from economically weaker background from the others. The average achievement scores of eligible and not-eligible students for mathematics for the of $4^{\text {th }}, 8^{\text {th }}$ and $12^{\text {th }}$ grades have been presented in Table- 1

TABLE - 1

\begin{tabular}{|c|c|c|c|c|c|c|}
\hline \multicolumn{7}{|c|}{$\begin{array}{l}\text { Average scale scores for Mathematics, grade } 4 \text { by National School Lunch Program eligibility and } \\
\text { year: } 2015,2013,2011 \text {, and } 2009\end{array}$} \\
\hline \multirow[t]{2}{*}{ Year } & \multirow[t]{2}{*}{ Jurisdiction } & \multicolumn{2}{|c|}{ Eligible } & \multicolumn{2}{|c|}{ Not eligible } & \multirow[b]{2}{*}{$\begin{array}{l}\text { Achievement } \\
\text { Gap }\end{array}$} \\
\hline & & $\begin{array}{c}\text { Average } \\
\text { scale score }\end{array}$ & $\begin{array}{l}\text { Standard } \\
\text { Error }\end{array}$ & $\begin{array}{c}\text { Average } \\
\text { scale } \\
\text { score } \\
\end{array}$ & $\begin{array}{l}\text { Standard } \\
\text { Error }\end{array}$ & \\
\hline 2015 & National & 229 & $(0.2)$ & 253 & $(0.3)$ & 24 \\
\hline 2013 & National & 230 & $(0.3)$ & 254 & $(0.2)$ & 24 \\
\hline 2011 & National & 229 & $(0.2)$ & 252 & $(0.2)$ & 23 \\
\hline 2009 & National & 227 & $(0.2)$ & 250 & $(0.3)$ & 23 \\
\hline \multicolumn{7}{|c|}{$\begin{array}{c}\text { Average scale scores for Mathematics, grade } 8 \text { by National School Lunch Program eligibility, and } \\
\text { year: } 2015,2013,2011 \text {, and } 2009\end{array}$} \\
\hline \multirow[t]{2}{*}{ Year } & \multirow[t]{2}{*}{ Jurisdiction } & \multicolumn{2}{|c|}{ Eligible } & \multicolumn{2}{|c|}{ Not eligible } & \\
\hline & & $\begin{array}{l}\text { Average } \\
\text { scale score }\end{array}$ & $\begin{array}{l}\text { Standard } \\
\text { Error }\end{array}$ & $\begin{array}{c}\text { Average } \\
\text { scale } \\
\text { score } \\
\end{array}$ & $\begin{array}{l}\text { Standard } \\
\text { Error }\end{array}$ & $\begin{array}{l}\text { Achievement } \\
\text { Gap }\end{array}$ \\
\hline 2015 & National & 268 & $(0.3)$ & 296 & $(0.3)$ & 28 \\
\hline 2013 & National & 270 & $(0.3)$ & 297 & $(0.3)$ & 27 \\
\hline 2011 & National & 269 & $(0.3)$ & 296 & $(0.3)$ & 27 \\
\hline
\end{tabular}




\begin{tabular}{|c|c|c|c|c|c|c|}
\hline $\mathbf{2 0 0 9}$ & National & 266 & $(0.3)$ & 294 & $(0.3)$ & 28 \\
\hline \multicolumn{7}{|c|}{ Average scale scores for Mathematics, grade 12 by National School Lunch Program eligibility and } \\
\hline Year & \multirow{2}{*}{ Jurisdiction } & \multicolumn{2}{|c|}{ Eligible 2015,2013 , and 2009 } \\
\cline { 2 - 7 } & & $\begin{array}{c}\text { Average } \\
\text { scale score }\end{array}$ & $\begin{array}{c}\text { Standard } \\
\text { Error }\end{array}$ & $\begin{array}{c}\text { Average } \\
\text { scale } \\
\text { score }\end{array}$ & $\begin{array}{c}\text { Standard } \\
\text { Error }\end{array}$ & $\begin{array}{c}\text { Achievement } \\
\text { Gap }\end{array}$ \\
\hline $\mathbf{2 0 1 5}$ & National & 137 & $(0.7)$ & 160 & $(0.7)$ & 23 \\
\hline $\mathbf{2 0 1 3}$ & National & 139 & $(0.7)$ & 162 & $(0.5)$ & 23 \\
\hline $\mathbf{2 0 0 9}$ & National & 137 & $(0.8)$ & 160 & $(0.8)$ & 23 \\
\hline
\end{tabular}

A perusal of the average achievement scores of $4^{\text {th }}$ graders has revealed that there has been an increase of merely 2 points in the case of eligible students and an increase on 3 scores for not-eligible students from 2009 to 2015. These results point out that there has not been a significant change in their achievement levels across 6 years, rather, the scores for the year 2015 have dropped one point each from 2013 to 2015, which suggest that the effect of the common core standards may be tapering off. It is interesting to note that the achievement gap between the two groups have, instead of narrowing, as expected, has grown wider. In the year 2009, i.e. before the implementation of the common core standards it was 23 whereas in the year 2015 it was 24. Similar patterns have been noticed for the students of $8^{\text {th }}$ and $12^{\text {th }}$ grades.

The average achievement scores of eligible and not-eligible students for reading for the of 4 th, 8 th and 12 th graders have been presented in Table2

TABLE-2

\begin{tabular}{|c|c|c|c|c|c|c|}
\hline \multicolumn{7}{|c|}{$\begin{array}{l}\text { Average scale scores for Reading, grade } 4 \text { by National School Lunch Program eligibility and year: } \\
\qquad 2015,2013,2011 \text {, and } 2009\end{array}$} \\
\hline \multirow[t]{2}{*}{ Year } & \multirow[t]{2}{*}{ Jurisdiction } & \multicolumn{2}{|c|}{ Eligible } & \multicolumn{2}{|c|}{ Not eligible } & \multirow[b]{2}{*}{$\begin{array}{l}\text { Achievement } \\
\text { Gap }\end{array}$} \\
\hline & & $\begin{array}{l}\text { Average } \\
\text { scale score }\end{array}$ & $\begin{array}{l}\text { Standard } \\
\text { Error }\end{array}$ & $\begin{array}{l}\text { Average } \\
\text { scale } \\
\text { score }\end{array}$ & $\begin{array}{l}\text { Standard } \\
\text { Error }\end{array}$ & \\
\hline 2015 & National & 209 & $(0.4)$ & 237 & $(0.3)$ & 28 \\
\hline 2013 & National & 207 & $(0.3)$ & 236 & $(0.3)$ & 29 \\
\hline 2011 & National & 207 & $(0.3)$ & 235 & $(0.3)$ & 28 \\
\hline 2009 & National & 206 & $(0.3)$ & 232 & $(0.3)$ & 26 \\
\hline \multicolumn{7}{|c|}{$\begin{array}{l}\text { Average scale scores for Reading, grade } 8 \text { by National School Lunch Program eligibility and year: } \\
\qquad 2015,2013,2011 \text {, and } 2009\end{array}$} \\
\hline \multirow[t]{2}{*}{ Year } & \multirow[t]{2}{*}{ Jurisdiction } & \multicolumn{2}{|c|}{ Eligible } & \multicolumn{2}{|c|}{ Not eligible } & \\
\hline & & $\begin{array}{l}\text { Average } \\
\text { scale score }\end{array}$ & $\begin{array}{l}\text { Standard } \\
\text { Error }\end{array}$ & $\begin{array}{l}\text { Average } \\
\text { scale } \\
\text { score }\end{array}$ & $\begin{array}{l}\text { Standard } \\
\text { Error }\end{array}$ & $\begin{array}{l}\text { Achievement } \\
\text { Gap }\end{array}$ \\
\hline 2015 & National & 253 & $(0.3)$ & 277 & $(0.3)$ & 24 \\
\hline 2013 & National & 254 & $(0.2)$ & 278 & $(0.3)$ & 24 \\
\hline 2011 & National & 252 & $(0.3)$ & 275 & $(0.3)$ & 23 \\
\hline 2009 & National & 249 & $(0.3)$ & 273 & $(0.3)$ & 24 \\
\hline \multicolumn{7}{|c|}{$\begin{array}{l}\text { Average scale scores for Reading, grade } 12 \text { by National School Lunch Program eligibility and year } \\
\qquad 2015,2013 \text {, and } 2009\end{array}$} \\
\hline Year & Jurisdiction & & & Not & sible & \\
\hline
\end{tabular}




\begin{tabular}{|c|c|c|c|c|c|c|}
\hline & $\begin{array}{c}\text { Average } \\
\text { scale score }\end{array}$ & $\begin{array}{c}\text { Standard } \\
\text { Error }\end{array}$ & $\begin{array}{c}\text { Average } \\
\text { scale } \\
\text { score }\end{array}$ & $\begin{array}{c}\text { Standard } \\
\text { Error }\end{array}$ & $\begin{array}{c}\text { Achievement } \\
\text { Gap }\end{array}$ \\
\hline $\mathbf{2 0 1 5}$ & National & 272 & $(0.8)$ & 295 & $(0.7)$ & 23 \\
\hline $\mathbf{2 0 1 3}$ & National & 274 & $(0.7)$ & 296 & $(0.6)$ & 22 \\
\hline $\mathbf{2 0 0 9}$ & National & 273 & $(0.7)$ & 294 & $(0.8)$ & 21 \\
\hline
\end{tabular}

The results of the achievement scores on reading tell us the same story as noticed above for mathematics. There is an increase on 3 and 4 points for the $4^{\text {th }}$ and $8^{\text {th }}$ grade eligible student, whereas there is a decrease of 1 point in the case of $12^{\text {th }}$ grades from this category. For the not-eligible category, there has been an increase of 5, 4 and 1 point increase across the three grades from 2009 to 2015 . Noticeable is the fact that the achievement gap between the two groups i.e. eligible and not eligible students from 2009 to 2015 has increased for $4^{\text {th }}$ graders by 2 points (from 26 to 28 ) and by two points for the $12^{\text {th }}$ graders (from 21 to 23 ), although it has remained constant for $8^{\text {th }}$ graders at 24 .

The average achievement scores for mathematics for the male and female students of 4th, 8th and 12th grades have been presented in Table- 3

TABLE - 3

\begin{tabular}{|c|c|c|c|c|c|c|}
\hline \multicolumn{7}{|c|}{$\begin{array}{c}\text { Average scale scores for Mathematics, grade } \mathbf{4} \text { by gender, year and jurisdiction: 2015, 2013, 2011, } \\
\text { and } 2009\end{array}$} \\
\hline \multirow[t]{2}{*}{ Year } & \multirow[t]{2}{*}{ Jurisdiction } & \multicolumn{2}{|c|}{ Male } & \multicolumn{2}{|c|}{ Female } & \multirow[b]{2}{*}{$\begin{array}{l}\text { Achievement } \\
\text { Gap }\end{array}$} \\
\hline & & $\begin{array}{c}\text { Average } \\
\text { scale } \\
\text { score }\end{array}$ & $\begin{array}{l}\text { Standard } \\
\text { Error }\end{array}$ & $\begin{array}{c}\text { Average } \\
\text { scale } \\
\text { score }\end{array}$ & $\begin{array}{l}\text { Standard } \\
\text { Error }\end{array}$ & \\
\hline 2015 & National & 241 & $(0.3)$ & 239 & $(0.3)$ & -2 \\
\hline 2013 & National & 242 & $(0.3)$ & 241 & $(0.2)$ & -1 \\
\hline 2011 & National & 241 & $(0.2)$ & 240 & $(0.2)$ & -1 \\
\hline 2009 & National & 241 & $(0.3)$ & 239 & $(0.3)$ & -2 \\
\hline \multicolumn{7}{|c|}{$\begin{array}{c}\text { Average scale scores for Mathematics, grade } 8 \text { by gender, year and jurisdiction: } 2015,2013,2011 \text {, } \\
\text { and } 2009\end{array}$} \\
\hline \multirow[t]{2}{*}{ Year } & \multirow[t]{2}{*}{ Jurisdiction } & \multicolumn{2}{|c|}{ Male } & \multicolumn{2}{|c|}{ Female } & \\
\hline & & $\begin{array}{c}\text { Average } \\
\text { scale } \\
\text { score }\end{array}$ & $\begin{array}{l}\text { Standard } \\
\text { Error }\end{array}$ & $\begin{array}{c}\text { Average } \\
\text { scale } \\
\text { score }\end{array}$ & $\begin{array}{l}\text { Standard } \\
\text { Error }\end{array}$ & $\begin{array}{l}\text { Achievement } \\
\text { Gap }\end{array}$ \\
\hline 2015 & National & 282 & $(0.3)$ & 282 & $(0.4)$ & 0 \\
\hline 2013 & National & 285 & $(0.3)$ & 284 & $(0.3)$ & -1 \\
\hline 2011 & National & 284 & $(0.3)$ & 283 & $(0.2)$ & -1 \\
\hline 2009 & National & 284 & $(0.3)$ & 282 & $(0.4)$ & -2 \\
\hline \multicolumn{7}{|c|}{$\begin{array}{l}\text { Average scale scores for Mathematics, grade } 12 \text { by gender, year and jurisdiction: 2015, 2013, and } \\
2009\end{array}$} \\
\hline \multirow[t]{2}{*}{ Year } & \multirow[t]{2}{*}{ Jurisdiction } & \multicolumn{2}{|c|}{ Male } & \multicolumn{2}{|c|}{ Female } & \\
\hline & & $\begin{array}{c}\text { Average } \\
\text { scale } \\
\text { score }\end{array}$ & $\begin{array}{l}\text { Standard } \\
\text { Error }\end{array}$ & $\begin{array}{c}\text { Average } \\
\text { scale } \\
\text { score }\end{array}$ & $\begin{array}{l}\text { Standard } \\
\text { Error }\end{array}$ & $\begin{array}{c}\text { Achievement } \\
\text { Gap }\end{array}$ \\
\hline 2015 & National & 153 & $(0.7)$ & 150 & $(0.6)$ & -3 \\
\hline 2013 & National & 155 & $(0.6)$ & 152 & $(0.6)$ & -3 \\
\hline 2009 & National & 155 & $(0.9)$ & 152 & $(0.7)$ & -3 \\
\hline
\end{tabular}


On mathematics, the male $4^{\text {th }}$ graders haven't indicated any increase in their achievement scores in 2015 over the one they had in 2009, it remained 241 . Whereas, the male students of $8^{\text {th }}$ grade and $12^{\text {th }}$ grades had dropped two points in their achievement scores (from 284 in 2009 to 282 in 2015 for $8^{\text {th }}$ grades, and from 155 to 153 for $12^{\text {th }}$ graders). There was a very marginal achievement gap across the years for all students, with the male students reporting 1 to 3 point higher achievement scores than the female students. These results suggest that the two gender groups differed from each other very marginally.

The average achievement scores for reading for the male and female students of 4 th, 8 th and 12 th grades have been presented in Table- 4

TABLE - 4

\begin{tabular}{|c|c|c|c|c|c|c|}
\hline \multicolumn{7}{|c|}{$\begin{array}{l}\text { Average scale scores for Reading, grade } 4 \text { by gender, year and jurisdiction: 2015, 2013, 2011, and } \\
\qquad 2009\end{array}$} \\
\hline \multirow[t]{2}{*}{ Year } & \multirow[t]{2}{*}{ Jurisdiction } & \multicolumn{2}{|c|}{ Male } & \multicolumn{2}{|c|}{ Female } & \multirow[b]{2}{*}{$\begin{array}{l}\text { Achievement } \\
\text { Gap }\end{array}$} \\
\hline & & $\begin{array}{c}\text { Average } \\
\text { scale } \\
\text { score }\end{array}$ & $\begin{array}{l}\text { Standard } \\
\text { Error }\end{array}$ & $\begin{array}{c}\text { Average } \\
\text { scale } \\
\text { score } \\
\end{array}$ & $\begin{array}{l}\text { Standard } \\
\text { Error }\end{array}$ & \\
\hline 2015 & National & 219 & $(0.4)$ & 226 & $(0.4)$ & -7 \\
\hline 2013 & National & 219 & $(0.3)$ & 225 & $(0.3)$ & -6 \\
\hline 2011 & National & 218 & $(0.3)$ & 225 & $(0.3)$ & -7 \\
\hline 2009 & National & 218 & $(0.3)$ & 224 & $(0.3)$ & -6 \\
\hline \multicolumn{7}{|c|}{$\begin{array}{c}\text { Average scale scores for Reading, grade } 8 \text { by gender, year and jurisdiction: } 2015,2013,2011 \text {, and } \\
2009\end{array}$} \\
\hline \multirow[t]{2}{*}{ Year } & \multirow[t]{2}{*}{ Jurisdiction } & \multicolumn{2}{|c|}{ Male } & \multicolumn{2}{|c|}{ Female } & \\
\hline & & $\begin{array}{c}\text { Average } \\
\text { scale } \\
\text { score }\end{array}$ & $\begin{array}{l}\text { Standard } \\
\text { Error }\end{array}$ & $\begin{array}{c}\text { Average } \\
\text { scale } \\
\text { score }\end{array}$ & $\begin{array}{l}\text { Standard } \\
\text { Error }\end{array}$ & $\begin{array}{l}\text { Achievement } \\
\text { Gap }\end{array}$ \\
\hline 2015 & National & 261 & $(0.2)$ & 270 & $(0.3)$ & -9 \\
\hline 2013 & National & 263 & $(0.3)$ & 273 & $(0.3)$ & -10 \\
\hline 2011 & National & 261 & $(0.3)$ & 270 & $(0.2)$ & -9 \\
\hline 2009 & National & 259 & $(0.3)$ & 269 & $(0.3)$ & -10 \\
\hline \multicolumn{7}{|c|}{ Average scale scores for Reading, grade 12 by gender, year and jurisdiction: 2015, 2013, and 2009} \\
\hline \multirow[t]{2}{*}{ Year } & \multirow[t]{2}{*}{ Jurisdiction } & \multicolumn{2}{|c|}{ Male } & \multicolumn{2}{|c|}{ Female } & \\
\hline & & $\begin{array}{c}\text { Average } \\
\text { scale } \\
\text { score }\end{array}$ & $\begin{array}{l}\text { Standard } \\
\text { Error }\end{array}$ & $\begin{array}{c}\text { Average } \\
\text { scale } \\
\text { score }\end{array}$ & $\begin{array}{l}\text { Standard } \\
\text { Error }\end{array}$ & $\begin{array}{c}\text { Achievement } \\
\text { Gap }\end{array}$ \\
\hline 2015 & National & 282 & $(0.6)$ & 292 & $(0.7)$ & -10 \\
\hline 2013 & National & 284 & $(0.6)$ & 293 & $(0.7)$ & -11 \\
\hline 2009 & National & 282 & $(0.7)$ & 294 & $(0.8)$ & -12 \\
\hline
\end{tabular}

The average achievement score for male $4^{\text {th }}$ grades on reading increased by one point from 218 in 2009 to 219 in $2015,8^{\text {th }}$ grade male students have reported a gain of two points (259 in 2009 to 261 in 2015), whereas the $12^{\text {th }}$ grades have not reported any change and their score remained 282 in 2009 and 2015 (although they had gained 2 points in 2013 but lost that gain by 2015). 
The average achievement scores for mathematics for the white, black and Hispanic students of 4th, 8th and 12th grades have been presented in Table- 5

TABLE -5

Average scale scores for Mathematics, grade 4 by race/ethnicity using 2011 guidelines, schoolreported [SRACE10], year and jurisdiction: 2015, 2013, 2011, and 2009

\begin{tabular}{|c|c|c|c|c|c|c|c|}
\hline \multirow[t]{2}{*}{ Year } & \multirow[t]{2}{*}{ Jurisdiction } & \multicolumn{2}{|c|}{ White } & \multicolumn{2}{|c|}{ Black } & \multicolumn{2}{|c|}{ Hispanic } \\
\hline & & $\begin{array}{c}\text { Average } \\
\text { scale } \\
\text { score }\end{array}$ & $\begin{array}{c}\text { Standard } \\
\text { Error }\end{array}$ & $\begin{array}{c}\text { Average } \\
\text { scale } \\
\text { score }\end{array}$ & $\begin{array}{c}\text { Standard } \\
\text { Error }\end{array}$ & $\begin{array}{c}\text { Average } \\
\text { scale } \\
\text { score }\end{array}$ & $\begin{array}{c}\text { Standard } \\
\text { Error }\end{array}$ \\
\hline 2015 & National & 248 & $(0.3)$ & 224 & $(0.4)$ & 230 & $(0.5)$ \\
\hline 2013 & National & 250 & $(0.2)$ & 224 & $(0.3)$ & 231 & $(0.4)$ \\
\hline 011 & National & 249 & $(0.2)$ & 224 & $(0.4)$ & 229 & $(0.3)$ \\
\hline 009 & National & - & $(\dagger)$ & - & $(\dagger)$ & - & $(\dagger)$ \\
\hline
\end{tabular}

Average scale scores for Mathematics, grade 8 by race/ethnicity using 2011 guidelines, schoolreported [SRACE10], year and jurisdiction: 2015, 2013, 2011, and 2009

\begin{tabular}{|c|c|c|c|c|c|c|c|}
\hline \multirow[t]{2}{*}{ Year } & \multirow[t]{2}{*}{ Jurisdiction } & \multicolumn{2}{|c|}{ White } & \multicolumn{2}{|c|}{ Black } & \multicolumn{2}{|c|}{ Hispanic } \\
\hline & & $\begin{array}{l}\text { Average } \\
\text { scale } \\
\text { score }\end{array}$ & $\begin{array}{c}\text { Standard } \\
\text { Error }\end{array}$ & $\begin{array}{c}\text { Average } \\
\text { scale } \\
\text { score }\end{array}$ & $\begin{array}{c}\text { Standard } \\
\text { Error }\end{array}$ & $\begin{array}{l}\text { Average } \\
\text { scale } \\
\text { score }\end{array}$ & $\begin{array}{l}\text { Standard } \\
\text { Error }\end{array}$ \\
\hline 2015 & National & 292 & $(0.3)$ & 260 & $(0.5)$ & 270 & $(0.5)$ \\
\hline 2013 & National & 294 & $(0.3)$ & 263 & $(0.4)$ & 272 & $(0.5)$ \\
\hline 011 & National & 293 & $(0.2)$ & 262 & $(0.5)$ & 270 & $(0.5)$ \\
\hline 2009 & National & - & $(\dagger)$ & - & $(\dagger)$ & - & $(\dagger)$ \\
\hline
\end{tabular}

Average scale scores for Mathematics, grade 12 by race/ethnicity using 2011 guidelines, schoolreported [SRACE10], year and jurisdiction: 2015, 2013, and 2009

\begin{tabular}{cccccccc} 
Year & Jurisdiction & \multicolumn{2}{c}{ White } & \multicolumn{2}{c}{ Black } & \multicolumn{2}{c}{ Hispanic } \\
& & $\begin{array}{c}\text { Average } \\
\text { scale } \\
\text { score }\end{array}$ & $\begin{array}{c}\text { Standard } \\
\text { Error }\end{array}$ & $\begin{array}{c}\text { Average } \\
\text { scale }\end{array}$ & $\begin{array}{c}\text { Standard } \\
\text { Error }\end{array}$ & $\begin{array}{c}\text { Average } \\
\text { scale }\end{array}$ & $\begin{array}{c}\text { Standard } \\
\text { Error }\end{array}$ \\
$\mathbf{2 0 1 5}$ & National & 160 & $(0.6)$ & 130 & $(1.0)$ & 139 & $(0.8)$ \\
$\mathbf{2 0 1 3}$ & National & 162 & $(0.6)$ & 132 & $(0.8)$ & 141 & $(0.8)$ \\
$\mathbf{2 0 0 9}$ & National & - & $(\dagger)$ & - & $(\dagger)$ & - & $(\dagger)$
\end{tabular}

\section{Achievement Gap Matrix}

\section{Grade - 4}

\begin{tabular}{|c|c|c|c|c|c|c|c|c|}
\hline \multicolumn{3}{|c|}{2011} & \multicolumn{3}{|c|}{2013} & \multicolumn{3}{|c|}{2015} \\
\hline & Black & Hispanic & & Black & Hispanic & & Black & Hispanic \\
\hline White & 26 & 25 & White & 26 & 25 & White & 26 & 24 \\
\hline Black & - & 1 & Black & - & 1 & Black & - & 2 \\
\hline Hispanic & - & - & Hispanic & - & - & Hispanic & - & - \\
\hline
\end{tabular}

Grade - 8

\begin{tabular}{|c|c|c|c|c|c|c|c|c|}
\hline \multicolumn{3}{|c|}{2011} & \multicolumn{3}{|c|}{2013} & \multicolumn{3}{|c|}{2015} \\
\hline & Black & Hispanic & & Black & Hispanic & & Black & Hispanic \\
\hline White & 31 & 23 & White & 31 & 22 & White & 32 & 22 \\
\hline Black & - & 8 & Black & - & 9 & Black & - & 10 \\
\hline Hispanic & - & - & Hispanic & - & - & Hispanic & - & - \\
\hline
\end{tabular}


Grade - 12

\begin{tabular}{|c|c|c|c|c|c|c|}
\hline & \multicolumn{3}{|c|}{2015} \\
\hline & Black & Hispanic & & & Black & Hispanic \\
\hline White & 30 & 21 & & White & 30 & 21 \\
\hline Black & - & 9 & Black & - & 9 \\
\hline Hispanic & - & - & & Hispanic & - & - \\
\hline
\end{tabular}

So far as mathematics is concerned, white $4^{\text {th }}$ graders lost one point from 2011 to 2015 (i.e. 249 to 248); black $4^{\text {th }}$ graders didn't indicate any gain across these years and had an average score of 224 for all the three reporting years; and the Hispanic students gained one point i.e. from 229 in 2011, they posted a score of 230 in 2015 . The startling fact that comes out from these results is that the achievement gap between white and black students hovered around 26 for the three reporting years and the difference between white and Hispanic students remained around 18. Between the Hispanic and black students, the former had an average higher score of 6 .

For the $8^{\text {th }}$ and $12^{\text {th }}$ graders, the same pattern of scores has emerged, with the white students scoring higher that the black student on an average by 31 points and the Hispanic students had an edge over the black students by about 9 points. The point that deserves to be noticed is that except the Hispanic $4^{\text {th }}$ grades (who posted an increase of one point from 2011 to 2015), most of all other groups of students either lost a point or two, or remained constant, i.e. there was no gain in achievement.

The average achievement scores for reading for the white, black and Hispanic students of 4th, 8th and 12th grades have been presented in Table6

TABLE -6

Average scale scores for Reading, grade 4 by race/ethnicity using 2011 guidelines, school-reported [SRACE10], year and jurisdiction: 2015, 2013, 2011, and 2009

Year Jurisdiction

White

Black

Hispanic

$\begin{array}{cccccc}\begin{array}{c}\text { Average } \\ \text { scale }\end{array} & \begin{array}{c}\text { Standard } \\ \text { Error }\end{array} & \begin{array}{c}\text { Average } \\ \text { scale } \\ \text { score }\end{array} & \begin{array}{c}\text { Standard } \\ \text { Error }\end{array} & \begin{array}{c}\text { Average } \\ \text { scale } \\ \text { score }\end{array} & \begin{array}{c}\text { Standard } \\ \text { Error }\end{array} \\ 232 & (0.3) & 206 & (0.5) & 208 & (0.8) \\ 232 & (0.3) & 206 & (0.5) & 207 & (0.5) \\ 231 & (0.2) & 205 & (0.5) & 206 & (0.5) \\ - & (\dagger) & - & (\dagger) & - & (\dagger)\end{array}$

Average scale scores for Reading, grade 8 by race/ethnicity using 2011 guidelines, school-reported [SRACE10], year and jurisdiction: 2015, 2013, 2011, and 2009

\begin{tabular}{lccccccc} 
Year & Jurisdiction & \multicolumn{2}{c}{ White } & \multicolumn{2}{c}{ Black } & \multicolumn{2}{c}{ Hispanic } \\
& & $\begin{array}{c}\text { Average } \\
\text { scale }\end{array}$ & $\begin{array}{c}\text { Standard } \\
\text { Error }\end{array}$ & $\begin{array}{c}\text { Average } \\
\text { scale }\end{array}$ & $\begin{array}{c}\text { Standard } \\
\text { Error }\end{array}$ & $\begin{array}{c}\text { Average } \\
\text { scale }\end{array}$ & $\begin{array}{c}\text { Standard } \\
\text { Error }\end{array}$ \\
& & score & & score & & score & \\
$\mathbf{2 0 1 5}$ & National & 274 & $(0.2)$ & 248 & $(0.5)$ & 253 & $(0.4)$ \\
$\mathbf{2 0 1 1}$ & National & 276 & $(0.3)$ & 250 & $(0.4)$ & 256 & $(0.5)$ \\
$\mathbf{2 0 0 9}$ & National & 274 & $(0.2)$ & 249 & $(0.5)$ & 252 & $(0.5)$ \\
National & - & $(\dagger)$ & - & $(\dagger)$ & - & $(\dagger)$
\end{tabular}

Average scale scores for Reading, grade 12 by race/ethnicity using 2011 guidelines, school-reported 
[SRACE10], year and jurisdiction: 2015, 2013, and 2009

\begin{tabular}{lccccccc} 
Year & Jurisdiction & \multicolumn{2}{c}{ White } & \multicolumn{2}{c}{ Black } & \multicolumn{2}{c}{ Hispanic } \\
& & $\begin{array}{c}\text { Average } \\
\text { scale }\end{array}$ & $\begin{array}{c}\text { Standard } \\
\text { Error }\end{array}$ & $\begin{array}{c}\text { Average } \\
\text { scale }\end{array}$ & $\begin{array}{c}\text { Standard } \\
\text { Error }\end{array}$ & $\begin{array}{c}\text { Average } \\
\text { scale }\end{array}$ & $\begin{array}{c}\text { Standard } \\
\text { Error }\end{array}$ \\
$\mathbf{2 0 1 5}$ & National & 295 & $(0.7)$ & 266 & $(1.1)$ & 276 & $(0.9)$ \\
$\mathbf{2 0 1 3}$ & National & 297 & $(0.6)$ & 268 & $(0.9)$ & 276 & $(0.9)$ \\
$\mathbf{2 0 0 9}$ & National & - & $(\dagger)$ & - & $(\dagger)$ & - & $(\dagger)$
\end{tabular}

Achievement Gap Matrix

\begin{tabular}{|c|c|c|c|c|c||c|c|c|}
\hline \multicolumn{3}{|c|}{ Grade - } \\
\hline \\
\hline
\end{tabular}

Grade - 8

\begin{tabular}{|c|c|c|c|c|c|c|c|c|}
\hline \multicolumn{3}{|c|}{2011} & \multicolumn{3}{|c|}{2013} & \multicolumn{3}{|c|}{2015} \\
\hline & Black & Hispanic & & Black & Hispanic & & Black & Hispanic \\
\hline White & 25 & 22 & White & 26 & 20 & White & 26 & 21 \\
\hline Black & - & 3 & Black & - & 2 & Black & - & 5 \\
\hline Hispanic & - & - & Hispanic & - & - & Hispanic & - & - \\
\hline
\end{tabular}

Grade - 12

\begin{tabular}{|c|c|c|c|c|c|}
\hline \multicolumn{3}{|c|}{2013} & \multicolumn{3}{|c|}{2015} \\
\hline & Black & Hispanic & & Black & Hispanic \\
\hline White & 29 & 21 & White & 29 & 19 \\
\hline Black & - & 8 & Black & - & 10 \\
\hline Hispanic & - & - & Hispanic & - & - \\
\hline
\end{tabular}

The results for reading have revealed the same pattern as in the case of mathematics so far as the achievement gap and the achievement within the group scores are concerned.

\section{Conclusion}

The results are univocal in pointing out the fact that even after the implementation of the common core standards seven years ago by most of the states across the nation, these have neither raised the achievement scores nor have reduced the achievement gaps among various student groups. Except marginal changes here and there, this gap still exists.

There is a need to revisit the standards with a focus on the specific content. Attention should be paid to the 'core' so as to strengthen the base that lays down a solid intellectual foundation on which the success of every child can be envisaged. It will prepare the students for college and career readiness.

On the other hand, teaching the new standards has been a major challenge for many classroom instructors, about half of whom are not fully prepared to teach the Common Core, estimated Michael Kirst, president of 
the California State Board of Education. He says "It requires a very different kind of classroom teaching," Kirst said of Common Core. "In education reform, the hardest thing to change is instruction within the classroom." (Fernandes and Oshiro, 2015). It seems that the implementation of these standards without any thoughtful ground work or any professional training to facilitate the transition, has resulted in no achievements across the grades, sex and the race. As Dunia Zeineddine, an 11th-grade math teacher at Polytechnic High School in Long Beach had observed "So if we see teachers teaching using the Common Core, it may become easier for us," She said "Because I'm sure we have all the components. We just need to know what it exactly they're asking for is.'(Guzman-Lopez, 2015). A prestigious project costing billions of dollars seems to have failed to produce any results as its start, its initiation itself doesn't seem to have been worked out properly. A deep introspection is called for and efforts should be made to prepare the professional task force, the teachers, ready for the specific content to ensure the efficacious implementation of these standards.

\section{References:}

1. Fernandes, D., and Oshiro, S. (2015). Half of California teachers not fully prepared to teach Common Core, top educator says. http://www.scpr.org/news/2015/03/23/50468/half-of-californiateachers-not-fully-prepared-to/

2. Guzman-Lopez, A. (2015). California teachers seeking more training to get Common Core right. http://www.scpr.org/news/2015/08/03/53507/california-teachersseeking-more-training-to-get-c/

3. Jones, A. G., \& King, J. E. (2012). The common core state standards: A vital tool for higher education. Change, 44(6), 37-43. doi:10.1080/00091383.2012.706529

4. Munson, L. (2011). What Students Really Need to Learn. Educational Leadership. Vol. 68 (6), 10-14.

5. National Assessment of Educational Progress (NAEP). https://nces.ed.gov/nationsreportcard/naepdata/dataset.aspx

6. Ostashevsky, L. (2016). More than five years after adopting Common Core, Kentucky's black-white achievement gap is widening. http://hechingerreport.org/five-years-adopting-common-corekentuckys-black-white-achievement-gap-widening/

7. Ravitch, D. (222). Left Back: A Century of Failed School Reforms. New York: Simon \& Schuster, 42-50.

8. Reese P. (2016). The achievement gap grew in 2016 under California Common Core. See it in your community. http://www.sacbee.com/site-services/databases/article37234650.html 
9. Robelen, W. (2013). "NAEP Report: A Closer Look at Trends in the Achievement Gap," Education Week, 28 June 2013.

10. Young, W. H. (2013). Common Core State Standards: The Achievement

Gap. https://www.nas.org/articles/common_core_state_standards_the_achi evement_gap\#_edn5 